\title{
Phonemic Interference of Local Language in Spoken English by Students of English Department of Lambung Mangkurat University
}

\author{
Fatchul Mu'in \\ English Department, Universitas Lambung Mangkurat Banjarmasin, South Kalimantan, Indonesia
}

\begin{abstract}
In the process of learning foreign language, learners often face a number of difficulties. The difficulties are related to learning new phonemics, new vocabulary, and various ways of arranging words into sentences in a new language. Learning English for students of Lambung Mangkurat University is a difficult matter. This is because their habit in using local language (Banjarese) is said to be strong, so it is difficult for them to change it. As a result, they simply apply the pattern and the phonemic rules of Banjarese language into English. This causes interference.In detail, the interference is caused by many differences between the two languages, namely Banjarese language and English. Banjarese language has 3 vowels, while English has 12 vowels. Banjarese language only has 3 diphthongs, whereas English has 9 diphthongs. Banjarese language only has 18 consonants, while English has 24 consonants. Given that the students' habit in speaking Banjarese language has been strong and there are many differences of phonemic elements, interference phenomenon cannot be avoided, which is, in this case, phonemic interference.
\end{abstract}

Index Terms-language learning problems, phonemics, Banjarese, students' habit, and phonemic interference

\section{INTRODUCTION}

In the effort of learning English, learners frequently face difficulties. According to Ramelan (1977), the difficulties faced by the learners are connected to learning new sound systems, new vocabulary, and various ways to arrange words into sentences (p. 6). The difficulties faced by learners can cause a number of errors in using the language being learned, both in speaking and writing. Dulay and Burt, for instance, posit that foreign language or second language learners always make errors. In this case, they state that "You cannot learn without goofing" (Richards, 1985, p. 95). The term 'goof' as what they propose means a deviation from phonetic and grammatical patterns from the original language (namely English).

The error made by learners as the result of the application or the use of the elements of first language while speaking or writing in second or foreign language is called as interference. Djinal et al. (1992) studied syntactical interference of Indonesian language in the use of written English by the students of English Department of Lambung Mangkurat University. There are some points which affect the errors in using languages. First, before learning foreign or second language, learners have mastered their first language and use it based on the system of the language. Each language has their own system which is different from other languages. The system of first language which is different from the language system being learned can cause the occurrence of language errors on the target language. Second, in the process of learning second or foreign language, the language of instruction used is the first language, so in learning the language the learners still think by using their first language.

Language errors caused by interference can occur on the language system which includes phonemics, morphology, syntax, and semantics. Moreover, interference occur both in spoken and written languages. This study is limited on the phonemic interference of local language (Banjarese) toward spoken language.

Research Problems

Based on the background of the study, the research problems are formulated as follows:

a. Do errors occur as the result of phonemic interference on the use of spoken language by the students of English Department of Lambung Mangkurat University, Banjarmasin?

b. Which phonemes of Banjarese language are applied in the use of spoken English by the students of English Department of Lambung Mangkurat University, Banjarmasin?.

\section{THEORETICAL FRAMEWORK}

A person who is learning a second or foreign language encounters difficulties in the learning process. This is what we have been aware of. Since childhood, they have been speaking in their first language. This language has been instilled in themselves and become a part of their habits. Their speech organs have been accustomed to produce speech sounds of the language. This habit obviously make it difficult for them to change the ways of moving their speech organs to produce speech sounds of a foreign language. 
Speaking is a habit. The acquisition of habit is through repetitive and continous practice. To acquire a local language, a person must goes through imitation process and repetition of utterances expressed by the people around them. They can speak in a manner like the people do after learning the language for six to eight years.

At the years ahead, they want to learn a second or foreign language, which means that they will learn a set of new language habit. Since they already had habits in their first language, the effort of learning a new language will be collided with their established language habit. From this point, they encounter problems in leanring the foreign language.

With the presence of the problems, they might apply the features of the language they have mastered into the language they are learning. Accordingly, interference phenomena will occur.

All in all, in the description of the theoretical framework, the researcher need to point up some issues related to interference, namely bilingualism, speakers who do interference (bilinguals) and the comparison between the phonemic system of Banjarese language and the phonemic system of English.

\section{Bilingualism}

An ideal concept of bilingualism refers to "native-like control of two languages". In this regard, Bloomfield in his book "Language" asserts:

In the extreme case of foreign language learning, the speaker becomes so proficient as to be indistinguishable from the native speaker around him. This happens occasionally in adult shifts of language and frequently in the childhood shifts just described. In the case where this perfect foreign learning is not accompanied by loss of the native language, it results in bilingualism, native-like control of two languages (Bloomfield, 1935, p. 56).

Thus, according to Bloomfield, if a person is learning a foreign language and can use the language perfectly without loosing their ability in their first language, the person has achieved "native-like control of two languages". However, if the person cannot differentiate the two languages during the contact, which means the two languages are used alternately, related to the use of the rules of each language, the person will do code-switching, code-mixing or interference.

There are other factors which influence speakers to use two languages alternately or do bilingualism. A person might have a perfect mastery two languages or reach "native-like control of two languages" linguistically, but in fact, the use of language is always affected by nonlinguistic factors. It can be stated that no matter how perfect the foreign language mastery of someone, there are features of their first language (the language they have mastered earlier) which appear in their utterances or writing when they use the foreign language.

Other delimitation on bilingualism is proposed by Mackey (in Fishman, ed., 1972, p. 555): "the alternate use of two or more languages by the same individual".

Bilingual

If the term 'bilingualism' is used to refer to "the alternate use of two or more languages by the same individual", bilingual means an individual who is involved in the practice of the use of two or more languages. Bilingual is an individual who use two or more languages alternately.

Bilinguals who are called as "incipient bilinguals' by Diebold J. are those who have bilingualism at the stage of learning and they have minimum bilingualism ability. These bilinguals have not made meaningful and complete utterances yet (in Soetomo, 1985, p. 11). A person who is bilingual having "native-like control of two languages" as stated by Bloomfield is called as equilingual or balanced lingual, terms proposed by Raffler-Engel (in Soetomo, 1985, p. $11)$.

\section{Interference}

Interference, as stated by Mackey (in Fishman, 1972, p. 569), is the use of elements of a language to another language while speaking or writing. The other definition of interference is a deviation which occurs toward the norms of each language in the practice of the use of two languages by individuals, as stated by Weinrich as follows:

The practice of alternately using two languages will be called bilingualism and the persons involved, bilingual. Those instances of deviation from the norms of either language will occur in the speech of bilinguals as a result of their familiarity with more than one language, i.e. as a result of language contact, will be referred to as interference phenomena (Weinrich, 1968, p. 1).

In the process of learning English (or can be said as a process to be bilingual speaker), the students are still at the level of "incipient bilingual" or bilingual speakers at the stage of learning. At this level, the students still experience problems in learning the system of speech sounds of the new language, new vocabulary, and the ways to arrange new words into new phrases, clauses, and sentences.

The interference phenomena which are said to be the results of mastering two or more languages by individuals might occur at all linguistic components, namely phonology/phonemics, morphology, syntax, and semantics. This study limits the analysis on the phonemic interference.

The phonemic interference which would be analyzed is the phonemic interference of local language (Banjarese) produced by the students in pronouncing English sounds. The analysis of the phonemic interference is conducted through contrastive analysis, namely comparing the phonemic systems of Banjarese language with English. This is meant to find pronunciation of English sounds which involves the phonemic system of Banjarese language. 
The following is the description of the comparison between phonemic system of Banjarese language and phonemic system of English.

The Comparison between Phonemic System of Banjarese Language and Phonemic System of English.

One of the characteristics of a language is that a language is always spoken. All people in this world, without looking at their race or ethnical groups, always speak in a certain language. This means that they have a certain way to communicate ideas by manipulating sounds produced by their speech organs.

Speech sounds are defined as sounds which are produced by humans' vocal organs or speech organs and consist of vowels and consonants. The consonants are combined with vowels to produce a number of morphemes or words. Morphemes or words in the huge number can also be combined to form bigger utterances, such as phrases, clauses, sentences and so on in a bigger number as well.

Thus, a language consists of two levels of structures, namely syntactic level structure and phonological level structure. At the syntactic level structure, sentences are represented or described as a combination of words, while at the phonological level structure, sentences can be represented as holistically combination of phonemes.

Phonemes have a very important role given that if two utterances are different in their pronunciation, the listener interpret these utterances as utterances with different meanings. A small difference which can distinguish utterances with different meanings is the difference of a phoneme (Gleason, 1981:9). The study of phoneme is called as phonemics or phonology. Before describing the phonemic system of Banjarese language and that of English, several definitions of phonemics and phonology are given as follows:

1. Phonology (is the study which) deals with the phonemes and sequences of phonemes (Gleason, 1961, p. 11).

2. Phonology is concerned with this kind of linguistic knowledge. Phonetics provides the means for describing speech sounds; phonology studies the ways in which speech sounds form systems and patterns in human language. The phonology of a language is then the system and pattern of the speech sounds (Fromkin \& Rodman, 1974, p. 102).

3. When we study speech sounds with a view to finding out the significant units of sounds in a given language, the science is called "phonemics". These significant units of sounds distinguish utterances and are called "phonemes" (Ramelan, 1977).

Referring to the mentioned scopes of phonology or phonemics, we can state that phonology or phonemics is a branch of linguistics which studies speech sounds by considering the function of the speech sounds to differentiate meanings. Moreover, phonemes from one language are definitely different from phonemes from other languages. Therefore, language learners obviously encounter a number of problems in imitating the phonemes from the foreign languages. As a result, they produce phonemes of foreign language with the phonemic systems of their own. This phenomenon actually happens toward foreign language learners (in this case English) whose Banjarese language background.

Phonemic System of Banjarese Language

A unit of speech sound which can differentiate meaning is called as phoneme. A phoneme, according to Fromkin and Rodman (1978, p. 107) is a more abstract unit than a phone. Because of the abstract characteristic of phoneme, one should know the phonological rules of a certain language to know how to pronounce the phoneme.

Vowels

Vowels in Banjarese language are /a/, /i/ and /u/. These vowels can be put at the initial position, middle position and final position.

Examples:

\begin{tabular}{|c|c|c|c|}
\hline Phonemes & Initial position & Middle position & Final position \\
\hline & /ilat/ 'tongue' & $\overline{\text { /kilik/ 'pickaback' }}$ & /tali/ 'rope' \\
\hline /a/ & /abah/'father' & /arah/'direction' & /asa/ 'one' \\
\hline /u/ & /uma/ 'mother' & /uyut/ 'great-grand mother' & /uhu/ 'bad' \\
\hline
\end{tabular}

In Banjarese language, there are vowel systme with the three phonemes, namely /a/, /i/, and /u/. Two of them have variation as follows:

a. /a/ can be realized as [ə]

/kamana/ - [komana] 'where'

b. /u/ can be realized as [o]

/butul/ - [botol]

/kawu/ - [kawo]

/rawut/ - [rawot]

'bottle'
'you'
'expression'

Consonants /y/

Consonants in Banjarese language are as follows: (/b/, /p/, /t/, /d/, /c/, /j/, /k/, /g/, /s/, /h/, /m/, /n/, /ny/, /y/, /1/, /r/, /w/,

Distributions of Consonants 


$\begin{array}{llll}\text { Phonemes } & \text { Initial position } & \text { Middle position } & \text { Final position } \\ \text { /b/ } & \text { /bara/ 'ember' } & \text { /tabas/'slash' } & - \\ \text { /p/ } & \text { /parak/ 'near' } & \text { /tapak/ 'knock' } & \text { /calap/ 'dye' } \\ \text { /t/ } & \text { /tada/ 'save' } & \text { /hatap/ 'roof' } & \text { /ilat/ 'tongue' } \\ \text { /d/ } & \text { /dara/ 'pigeon' } & \text { /hadap/ 'to face' } & - \\ \text { /c/ } & \text { /calap/ 'dye' } & \text { /racap/ 'frequently' } & - \\ \text { /j/ } & \text { /jajak/ 'stampede' } & \text { /tajak/ 'stick' } & - \\ \text { /k/ } & \text { /karak/ 'crust' } & \text { /bakal/ 'candidate' } & \text { /parak/ 'near' } \\ \text { /g/ } & \text { /garu/ 'garuk' } & \text { /sagan/ 'for' } & - \\ \text { /s/ } & \text { /saday/ 'enough' } & \text { /pasan/ 'bundle' } & \text { /hampas/ 'throw' } \\ \text { /h/ } & \text { /haday/ 'wait' } & \text { /rahat/ 'frequent' } & \text { /usah/'chase' } \\ \text { /m/ } & \text { /mara/ 'direction' } & \text { /humap/ 'sultry' } & \text { /masam/'sour' } \\ \text { /n/ } & \text { /nani/ 'this one' } & \text { /manay/ 'win' } & \text { /sagan/ 'for' } \\ \text { /ny/ } & \text { /nyariy/ 'loud' } & \text { /hanyar/ 'new' } & - \\ \text { /y/ } & \text { /naran/ 'name' } & \text { /bunul/ 'stupid' } & \text { /gurin/ 'sleep' } \\ \text { /l/ } & \text { /lapar/ 'hungry' } & \text { /tilam/ 'mattress' } & \text { /sumpal/'plug' } \\ \text { /r/ } & \text { /rancak/ 'frequently' } & \text { /karap/ 'kerap' } & \text { /libar/ 'wide' } \\ \text { /w/ } & \text { /warik/ 'monkey' } & \text { /hawar/ 'throw' } & - \\ \text { /y/ } & \text { /yakin/ 'sure' } & \text { /uyah/ 'salt' } & -\end{array}$

\section{Diphthongs}

Diphthongs in Banjarese language are as follows:

$\begin{array}{lll}\text { /ai/ } & \text { /mamai/ } & \text { 'scold' } \\ \text { /au/ } & \text { /mamau/ } & \text { 'lost' } \\ \text { /tangui/ } & \text { 'broadleaf hat' }\end{array}$

\section{Distribution of Diphthong}

$\begin{array}{llll}\text { Diphthong } & \text { Initial position } & \text { Middle position } & \text { Final position } \\ \text { /ai/ } & - & \text { /kaina/ 'later' } & \text { /balanai/ 'pot' } \\ \text { /au/ } & - & \text { /sauda/ 'no' } & \text { /badau/ 'large wounds' } \\ \text { /ui/ } & - & \text { /kuitan/ 'parent' } & \text { /rupui/ 'crumble' }\end{array}$

\section{The Phonemic System of English}

The number of English phonemes is more than the number of Banjarese phonemes. From this fact, it can be assumed that English learners with Banjarese language background would encounter many difficulties at their initial learning stages.

\section{Vowels}

English vowels are classified into three groups:

a. Front, Central and Back Vowels

b. High, Mid, Low Vowels

The terms 'high', 'mid' and 'low' in regard to vowel sounds refer to the differences of tongue height. The vowels are /i:/, /i/, /u:/, /u/ (for high vowels); /e/, /a:/, and /a/ (for mid vowels); and /æ/, /০/, /^/, and / :/ (for low vowels). If the tongue is lifted and it reaches the highest position, high vowels are produced. If the tongue position is under the highest position, the produced vowels are mid vowels. Moreover, if the tongue is at low position, low vowels are produced.

c. Rounded and Unrounded Vowels

This classification is related to lip shape while producing speech sounds. If both lips (upper and lower lips) round while producing the sounds, vowels produced are round vowels. Round vowels are /o/, / :/, /u/, / / and /u:/.

\section{Diphthong}

There are 5 closing diphthongs and 4 centering diphthongs in English. The first 5 diphthongs are /eı/, /ou/, /ol/, /au/, and /o// and the last 4 diphthongs are /ı/, /uə/, /عə/, and /əə/.

\section{Consonants}

The classification of consonants can be explained as follows:

a. Based on the place where optimum obstruction occurs, English consonants can be classified as follows:

1. Bilabial consonants: /p/, /b/, /m/, /w/

2. Labiodental consonants: /f/ /v/

3. Dental consonants: $/ \theta /, / \delta /$

4. Alveolar consonants: /t/, /d/, /n/, /l/, /s/, /z/, / /, /3/, /r/, /t J/, /dz/

5. Palatal consonants: /y/

6. Velar consonants: $/ \mathrm{k} /, / \mathrm{g} /, / \mathrm{y} /$

7. Glotal consonants: / $/, / \mathrm{h} /$

b. Based on manner of obstruction, English consonants consists of:

1. Plosive consonants : /p/, /b/, /t/,/d/,/k/,/g/,///

2. Africative consonants: /t $\int /, / \mathrm{d} z /$

3. Fricative consonants: /f/, /v/, / / /, / //, /s/, /z/, / /, /3/, /h/

4. Nasal consonants: $/ \mathrm{m} /, / \mathrm{n} /, / \mathrm{n} /$ 
5. Lateral consonants: /1/

6. Semi-vowel consonants: /y/, /w/

c. Based on the activity of the vocal cords, English consonants are calssified as follows:

1. Voiced consonants: /b/, /d/, /dz/, /g/, /v/, / / /, /z/, / / /

2. Voiceless consonants: /p/, /t/, /t $\mathrm{S} /, / \mathrm{k} /, / \mathrm{f} /, / \theta /, / \mathrm{s} /, / \mathrm{S} /$

\section{Possibilities of Phonemic Interference}

It has been explained earlier that the phonemic system of Banjarese language is much different from the phonemic system of English. English phonemes vary more than Banjarese phonemes do. Thus, it can be assumed that learners with Banjarese language background will have many problems in pronouncing English phonemes in accordance with English phonology.

The researcher assumed some possibilities of phonemic interference of Banjarese language into English utterances by English learners, namely the students of English Department Lambung Mangkurat University whose native language is Banjarese language, as follows:

1. Vowel /i:/ can be found in the following English words:

$\begin{array}{llll}\text { meet } & \text { /mi:t/ } & \text { key } & \text { /ki:/ } \\ \text { he } & \text { /hi:/ } & \text { beat } & \text { /bi:t/ } \\ \text { see } & / \mathrm{si}: / & \text { bean } & \text { /bi:n/ } \\ \text { bee } & \text { /bi:/ } & \text { least } & / l i: s t /\end{array}$

These phonemes are not found in Banjarese language. This may let interference take place with the use of Banjarese phonem /i/. Thus, the possibility of representation of phonem /i:/ as /i/ is as follows:

$\begin{array}{ll}/ \mathrm{mit} / & / \mathrm{ki} / \\ / \mathrm{hi} / & / \mathrm{bit} / \\ / \mathrm{si} / & / \mathrm{bin} / \\ / \mathrm{bi} / & / l i s t /\end{array}$

This type of pronunciation error is classified into interference a.

2. Vowel /æ/ in English can be found in the following words:

$\begin{array}{llll}\text { band } & / \mathrm{bænd} / & \text { land } & / \text { lænd/ } \\ \text { bad } & / \mathrm{bæd} / & \text { sad } & / \mathrm{sæd} / \\ \text { bat } & / \mathrm{bæt} / & \text { bag } & / \mathrm{bæg} / \\ \text { man } & / \mathrm{mæn} / & \text { gas } & / \mathrm{gæs} /\end{array}$

These phonemes do not exist in Banjarese language. This makes the students replace phoneme /æ/ with the existing phoneme in Banjarese language, which is /a/, so interference is likely to occur, as can be seen in the following phoneme pronunciation:

$\begin{array}{ll}\text { /band/ } & \text { /land/ } \\ \text { /bad/ } & \text { /sad/ } \\ \text { /bat/ } & \text { /bag/ } \\ \text { /man/ } & \text { /gas/ }\end{array}$

This type of pronunciation error is then classified into interference $b$.

3. Since there are no phonemes $/ 0 /, / 0: /$ and $/ \mathrm{u}: /$ in Banjarese language, these phonemes are likely to be replaced with phoneme $/ \mathrm{u} /$. The replacement can be seen in the following examples:

$\begin{array}{lll}\begin{array}{ll}\text { Pronunciation in English } \\ \text { gone }\end{array} & \text { /gon/ } & \text { Pronunciation in Banjarese phonology } \\ \text { lodge } & / \text { lodz/ } & \text { /lud/ } \\ \text { cord } & / \mathrm{ko:d} / & / \mathrm{kud} / \\ \text { fool } & / \mathrm{fu}: 1 / & / \mathrm{ful} /\end{array}$

This type of pronunciation error is then classified into interference $c$.

4. The absence of phoneme / $/$ :/ in Banjarese language creates a possibility of the use of phoneme /i/ in representing phoneme $/ \varepsilon /$ in English. The examples are as follows:

\begin{tabular}{lll}
\multicolumn{2}{l}{ Pronunciation in English } & Pronunciation in Banjarese phonology \\
bird & /bə:d/ & /bid/ \\
first & /fə:st/ & /pist/ \\
firm & $/ \mathrm{fə:m} /$ & $/ \mathrm{pim} /$
\end{tabular}

This type of pronunciation error is then classified into interference $\mathrm{d}$.

5. The absence phoneme /a:/ in Banjarese language creates a possibility of the use of /a/ to pronounce the following words: 


$\begin{array}{lll}\text { Pronunciation in English } & \text { Pronunciation in Banjarese phonology } \\ \text { far } & \text { /fa:/ } & \text { /fa/ } \\ \text { card } & \text { /ka:d/ } & \text { /kad/ } \\ \text { hard } & \text { /ha:d/ } & \text { /had/ } \\ \text { heart } & \text { /ha:t/ } & \text { /hat/ }\end{array}$

This type of pronunciation error is then classified into interference e.

6. Phonemic interference is likely to occur because of the absence diphthong /ov/ in Banjarese language. The phoneme is replaced with /u/. For examples:

$\begin{array}{lll}\text { Pronunciation in English } & \text { Pronunciation in Banjarese phonology } \\ \text { code } & \text { /koud/ } & \text { /kud/ } \\ \text { rode } & \text { /roud/ } & \text { /rud/ } \\ \text { tone } & / \text { toun/ } & / \text { tun/ } \\ \text { coast } & / \text { koust/ } & \text { /kust/ }\end{array}$

This type of pronunciation error is then classified into interference $f$.

7. The next possibility of the occurrence of phonemic interference is because of the absence of diphthong /el/ in Banjarese language. This phoneme is replaced with /// or /al/ (diphthong /al/ exists in Banjarese language). The examples are as follows:

$\begin{array}{ll}\text { Pronunciation in English } \\ \text { raid } & \text { /resd/ } \\ \text { main } & / \mathrm{metn} / \\ \text { late } & \text { /lett/ } \\ \text { wait } & \text { /weit/ }\end{array}$

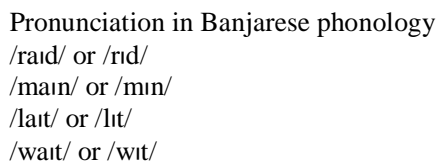

This type of pronunciation error is then classified into interference $\mathrm{g}$.

8. The other possibility of the occurrence of phonemic interference is because there is no diphthong /av/ in Banjarese language. This phoneme is then replaced with $/ \mathrm{au} /$ or $/ \mathrm{u} /$. The examples are as follows:

$\begin{array}{ll}\text { Pronunciation in English } & \text { Pronunciation in Banjarese phonology } \\ \text { how } / \text { hav/ } & \text { /hau/ or /hu/ } \\ \text { found /faund/ } & \text { /faun/ or /fun/ }\end{array}$

This type of pronunciation error is then classified into interference $h$.

9. Regarding the aspiration, both languages have differences one another. Aspiration is not recognized in Banjarese language. English phonemes $/ \mathrm{p} /, \quad / \mathrm{t} /$, and $/ \mathrm{k} /$ are realized with aspiration if they are located at the initial syllable followed by stressed vowels, as said by Fromkin and Rodman (1978:116) that "Aspirate voiceless stops at the beginning of a word or syllable before stressed vowels". "Voiceless stops" are /p/, /t/, and /k/.

Consequently, these phonemes are not aspirated by the students. The examples are as follows:

$\begin{array}{lll}\text { Pronunciation in English } & \text { Pronunciation in Banjarese phonology } \\ \text { time } & / \mathrm{t}^{\mathrm{h}} \text { aim/ } & / \text { taim/ } \\ \text { pen } & / \mathrm{p}^{\mathrm{h}} \varepsilon \mathrm{n} / & / \mathrm{pen} / \\ \text { key } & / \mathrm{k}^{\mathrm{h}} \mathrm{i}: / & / \mathrm{ki} /\end{array}$

This type of pronunciation error is then classified into interference $i$.

10. English phonemes /f/ and /v/ are likely to be replaced with phoneme /p/ by the students. This is because of the absence of these phonemes in Banjarese language. The examples can be seen in the following words and pronunciation:

$\begin{array}{ll}\text { Pronunciation in English } & \text { Pronunciation in Banjarese phonology } \\ \text { firm /fə:m/ } & \text { /pə:m/ } \\ \text { wife /war/ } & \text { /waip/ } \\ \text { movement/mu:vmənt/ } & \text { /mupmənt/ } \\ \text { love /lıv/ } & \text { /lap/ }\end{array}$

This type of pronunciation error is then classified into interference $j$.

11. Phonemes /b/, /d/ and /g/ are recognized both in English and Banjarese language. When distributed, these phonemes only appear at the initial and middle position in Banjarese language, whereas they appear at the initial, middle, and final position in English. Since these phonemes never appear at the final position in Banjarese language, the students who are learning English tend to replace the phonemes $/ \mathrm{b} /, / \mathrm{d} /$ and $/ \mathrm{g} / \mathrm{with} / \mathrm{p} / \mathrm{h} / \mathrm{t} /$, and $/ \mathrm{k} /$ respectively. It means that phoneme $/ \mathrm{b} /$ is replaced with $/ \mathrm{p} /, / \mathrm{d} /$ is replaced with $/ \mathrm{t} /$ and $/ \mathrm{g} /$ is replaced with $/ \mathrm{k} /$. The examples can be seen in the following: 


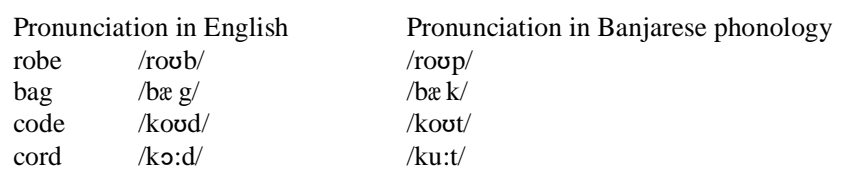

This type of pronunciation error is then classified into interference $\mathrm{k}$.

12. In English, phonemes $/ \theta /$ and $/ \delta /$ exist while they do not in Banjarese language. Orthographically, the phonemes are symbolized as $t$. In Banjarese language phonemes $/ \mathrm{t} /$ and $/ \mathrm{d} /$ are recognized. The English phonemes $/ \theta /$ and $/ \delta /$ are high likely to be pronounced by the students with Banjarese language as $/ \mathrm{t} /$ and $/ \mathrm{d} /$. The examples can be seen in the following:

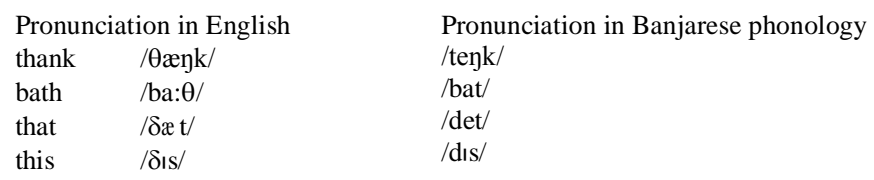

This type of pronunciation error is then classified into interference 1.

13. In English, phonemes /s/ and /z/ are two different phonemes. These phonemes can appear at all positions: initial, middle, and final. In contrast, Banjarese language only recognizes one phoneme, namely /s/. Thus, the students who are learning English will face difficulties in producing sound or phoneme /z/ and they tend to replace it with phoneme /s/ as it exists in their language. The examples can be seen in the following:

$$
\begin{array}{lll}
\text { Pronunciation in English } & \text { Pronunciation in Banjarese phonology } \\
\text { zink } & \text { /zınk/ } & \text { /sink/ } \\
\text { lazy } & \text { /leizi:/ } & \text { /lisi/ }
\end{array}
$$

This type of pronunciation error is then classified into interference $\mathrm{m}$.

14. In English, there are phonemes $/ \mathrm{J} /$ and $/ 3 /$, while no such phonemes exist in Banjarese language. This creates

\begin{tabular}{|c|c|c|}
\hline & Pronunciation in Banjarese phonology \\
\hline \multicolumn{2}{|c|}{$\begin{array}{l}\text { Pronunciation in English } \\
\text { she / } \mathrm{Si} / /\end{array}$} & $/ \mathrm{si} /$ \\
\hline shin & /Si:n/ & $/ \sin /$ \\
\hline ash & $/ æ \int /$ & læs/ \\
\hline mash & $/ \mathrm{m} \int /$ & /mæs/ \\
\hline rouge & /ru:3/ & /rus/ \\
\hline mirage & /mıra:3/ & /miras/ \\
\hline camou & e /kæmufla:3/ & /kamuflas/ \\
\hline
\end{tabular}
problems for the students with Banjarese language background. They tend to replace the phonemes with phoneme /s/ like what exists in their language. The examples are as follows:

This type of pronunciation error is then classified into interference $\mathrm{n}$.

Based on the aforementioned description of interference, it can be concluded that the students of English Department, Faculty of Teacher Training and Education, Lambung Mangkurat University, Batch 2016/2017 are the students who are assumed to still have difficulties in pronouncing English phonemes. This is because the phonemic system of local language (namely Banjarese language) is much different from the phonemic system of English.

The difficulties may emerge because of the influence of the phonemic system of Banjarese language, which has been mastered and used in daily lives, toward English which is being learned. The influence of phonemic system of Banjarese language toward the phonemic system of English is called as phonemic interference. (Besides phonemic interference, there are other terms of linguistic interference, namely morphological, syntactical, and semantic interferences).

\section{RESEARCH METHOD}

\section{A. Basic Assumptions}

The basic assumptions in this study are as follows:

a. Bilingualism

Bilingualism is the use of two or more languages alternately by individuals.

b. Interference

Interference is a deviation occurred on the norms of each language in the practice of using two or more languages by individuals. Interference can occur on all linguistic components. In this study, the focus of the problems is on phonemic interference.

c. Contrastive Analysis 
Contrastive analysis is the analysis conducted on the differences between target language and source language. The differences can occur on all linguistic components. In this study, the analysis was conducted on the phonemic components.

\section{B. Hypothesis}

The hypothesis of this study was formulated as follows:

"Errors occur in the realization or the representation of English phonemes resulted from the interference of phonemics system of Banjarese language in spoken language of the students of English Department, Lambung Mangkurat University."

\section{Research Method}

Research method employed was descriptive method. Descriptive method describes and interprets current condition. Descriptive research is related to the existing condition or relationship, current practices, beliefs, perspectives or attitudes, processes, or prevailing tendencies. The main objective of descriptive research is to picture and describe a condition naturally as it is at the moment (Ary et al., 1979, p. 25).

Regarding the characteristics of the research problems and the types of the data to be obtained in this study, the phonemic interference of Banjarese language which occurred in spoken English of the students of English Department. Lambung Mangkurat University. The spoken English was uttered by the students while they were taking Intensive Course.

\section{Population and Sample}

Population is a number of individuals who have the least similar characteristics. The population of this study comprised all the students of English Department, Lambung Mangkurat University who were taking Intensive English Course and their first language is Banjarese language. There were 85 students whose native language is Banjarese language.

The number of the students was relatively big. In order to guarantee that the respondents could be accessible during the field observation, it is necessary to take a part of them for being the research samples. In this study, random sampling technique was used. Using this sampling technique, 45 students were chosen as the research samples.

\section{E. Data Collection Technique}

The data were obtained by assigning the students to read predetermined English texts. The texts were created by considering the phonemes which were prone to interference.

\section{F. Data Analysis}

The data analysis was conducted by collecting the words that were incorrectly pronounced. Among the incorrectlypronounced words, some words were selected on the basis of errors caused by the phonemic interference of Banjarese language. Then, the selected words were categorized based on the types of interference. The categorization was performed by using an instrument in the form of the detail of the interference types as presented and described in Literature Review part.

\section{DISCUSSION}

\section{A. Data Description}

The data of this study were English words which were pronounced or uttered incorrectly according to English phonemics. The words were obtained from the recording result on the pronunciation of sentences or words during speaking or reading aloud activities of the students of English Department, Lambung Mangkurat University.

In analyzing the data, first, the words which were incorrectly pronounced (not suitable with English phonemics) were found. Among the number of the incorrect pronunciations, pronunciation errors resulted from the phonemic interference of Banjarese language toward English were searched. The words with incorrect pronunciation were categorized based on the types of the interference which occurs. The instrument of categorization can be seen at the end of Chapter II (Literature Review).

Based on the analysis, the data of phonemic interference were obtained as follows:

1. Vowel /i:/ was replaced with vowel /i/.

Examples:

\begin{tabular}{|c|c|c|}
\hline \multicolumn{2}{|c|}{ English words } & pronounced as \\
\hline $\mathrm{He}$ & /hi:/ & /hi/ \\
\hline see & /si:/ & /si/ \\
\hline key & /ki:/ & $/ \mathrm{ki} /$ \\
\hline beneath & /bıni: $\theta /$ & /bınit/ \\
\hline
\end{tabular}

2. Vowel /u:/ was replaced with vowel /u/.

Examples: 


$\begin{array}{lll}\begin{array}{ll}\text { English words } \\ \text { prove }\end{array} & \text { /pru:v/ } & \text { pronounced as } \\ \text { crew } & / \text { pru:/ } & / \text { kru/ } \\ \text { rule } & \text { /ru:1/ } & \text { /rul/ }\end{array}$

3. Vowel /a:/ was replaced with /a/.

Examples:

$\begin{array}{lll}\text { English words } & & \text { pronounced as } \\ \text { laugh } & \text { /la:f/ } & \text { /laf/ } \\ \text { guard } & \text { /ga:d/ } & \text { /gad/ } \\ \text { park } & \text { /pa:k/ } & \text { /pak/ }\end{array}$

4. Diphthong /ou/ was replaced with /u/.

Examples:

$\begin{array}{lll}\text { English words } & & \text { pronounced as } \\ \text { code } & / \text { koud/ } & / \text { kud/ } \\ \text { no } & / \text { nou/ } & / \text { nu/ } \\ \text { show } & / \text { ou/ } & / \mathrm{su} / \\ \text { bone } & / \text { boun/ } & / \text { bun/ }\end{array}$

5. Diphthong /eı/ was replaced with /I/ or /aı/.

Examples:

\begin{tabular}{|c|c|c|}
\hline \multicolumn{3}{|l|}{ English words } \\
\hline late & /lett/ & $/ \mathrm{lt} t /$ \\
\hline tail & /teıl/ & $/ \mathrm{t} \mathrm{l} / /$ \\
\hline fail & /feıl/ & /fall/ \\
\hline raid & /reıd/ & /raıd/ \\
\hline bay & /bel/ & $/ \mathrm{bal} /$ \\
\hline
\end{tabular}

6. Diphthong /au/ was replaced with /u/.

Examples:

$\begin{array}{lll}\begin{array}{ll}\text { English words } \\ \text { allow }\end{array} & \text { /ə'lau/ } & \text { pronounced as } \\ \text { count } & \text { /kaunt/ } & \text { /kun/ } \\ \text { how } & \text { /hau/ } & / \text { hu/ } \\ \text { town } & \text { /taun/ } & / \text { tun/ }\end{array}$

7. Consonants /p, t, k/ were not aspirated.

Examples:

\begin{tabular}{lll}
\multicolumn{2}{l}{ English words } & pronounced as \\
key & $/ \mathrm{k}^{\mathrm{h}} \mathrm{i} / /$ & $/ \mathrm{ki} /$ \\
people & $/ \mathrm{p}^{\mathrm{h}}$ i:pl/ & $/ \mathrm{pipl} /$ \\
time & $/ \mathrm{t}^{\mathrm{h}}$ aim/ & $/$ taim/
\end{tabular}

8. Consonants /f, v/ were replaced with /p/.

Examples:

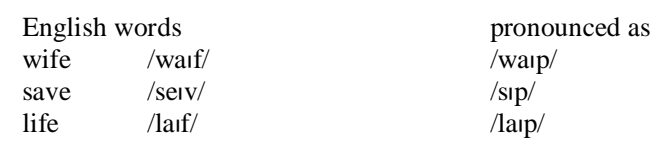

9. Consonant /b/ was replaced with /p/, /d/ was replaced with /t/. And /g/ was replaced with /k/.

Examples:

$\begin{array}{lll}\text { English words } & & \text { pronounced as } \\ \text { rob } & \text { /roub/ } & \text { /roup/ } \\ \text { robbed } & \text { /roubd/ } & \text { /roubt/ } \\ \text { bag } & \text { /bæg/ } & \text { /bæk/ }\end{array}$

10. Consonant $/ \theta /$ was replaced with $/ \mathrm{t} /$, consonant $/ \delta /$ was replaced with $/ \mathrm{d} /$. Examples: 


$\begin{array}{lll}\text { English words } & & \text { pronounced as } \\ \text { think } & / \theta \mathrm{ink} / & / \text { tij/ } \\ \text { theory } & / \theta \text { เrr } / & / \text { tirri } / \\ \text { this } & / \delta \mathrm{is} / & / \mathrm{d} \mathrm{s} / \\ \text { they } & / \delta \mathrm{el} / & / \mathrm{del} /\end{array}$

11. Consonant /z/ was replaced with /s/. Examples:

\begin{tabular}{lll}
\multicolumn{2}{l}{ English words } & pronounced as \\
because & /biko:z/ & /bikos/ \\
his & /hız/ & /his/ \\
houses & /hauzı/ & /hauses/
\end{tabular}

12. Consonants / $\int, 3 /$ were replaced with $/ \mathrm{s} /$. Examples:

$\begin{array}{lll}\text { English words } & \text { pronounced as } \\ \text { she } & / S \mathrm{i}: / & \text { /si/ } \\ \text { ship } & / \int \mathrm{ip} / & / \mathrm{sip} / \\ \text { pleasure } & \text { /ple3ə:/ } & \text { /ples:/ } \\ \text { treasure } & \text { /tre3ə:/ } & \text { /tres:/ }\end{array}$

\section{B. Discussion}

From the obtained data on the errors resulted from interference $\underline{a}$, it can be explained as follows:

In English, speech sounds /i:/, ///, /i/ exist, while in Banjarese language, only sound /i/ exists, like in words $i k a m$ /ikam/, ibit /ibit/, and inggih /ingih/. This causes difficulties for the students whose language background is Banjarese language to pronounce /i:/ as in word see /si:/. Therefore, there is a tendency for them to pronounce /si/.

(1) From the obtained data on the errors resulted from interference $\underline{c}$, it can be explained as follows:

Not all the vowels are affected by interference $\underline{c}$ as explained in the previous point. To be specific, all vowels /o, o:, $\mathrm{u}: /$ are not replaced by /u/. The interference only occurred on vowel /u:/ in which /u:/ was replaced with /u/. The replacement of vowel /u:/ takes place since in Banjarese language only sound / $\mathrm{u} / \mathrm{is}$ known as in word urak /urak/ and buruk/buruk/.

(2) From the obtained data on the errors resulted from interference e , it can be explained as follows:

Since in Banjarese language only vowel /a/ is known, the students whose Banjarese language background find it difficult to pronounce sound /a:/, like in word far /fa:/. They tend to pronounce it /fa/.

(3) In the case of interference $\underline{\mathrm{f}}$, it can be explained that diphthong /ou/ does not exist in Banjarese language. Consequently, there is a tendency that the students whose Banjarese language background replace diphthong /ou/ with $/ \mathrm{u} /$ since sound $/ \mathrm{u} / \mathrm{is}$ close to diphthong /ou/. They pronounce word code with sound /u/, namely $/ \mathrm{kud} / \mathrm{which}$ is supposed to be /koud/.

(4) Regarding interference g, the replacement of /eı/ with / / is caused by the absence of diphthong /eı/ in Banjarese language. Students with Banjarese language background tend to replace diphthong /el/ with /// or /al/ since they are already accustomed in using it in their language, such as in word ilat /ilat/ and kaina /kaina/. The word late was pronounced /lit/, and fail was pronounced /fail/.

(5) Regarding interference $\underline{\mathrm{h}}$, diphthong /au/ is not known in Banjarese language. Similar to interference $\underline{\mathrm{f}}$, the closest sound to $/ \mathrm{au} / \mathrm{is} / \mathrm{u} /$. In Banjarese language, sound /u/ exists. Therefore, the students with Banjarese language background replace the sound /au/ with /u/. For instance, word town /taun/ was pronounced as /tun/.

(6) In the case of interference $\underline{\mathrm{i}}$, in Banjarese language there is no aspiration for sounds $/ \mathrm{p} /, \mathrm{t} /$ and $/ \mathrm{k} /$ in certain position. In contrast, English recognizes aspiration for sounds $/ \mathrm{p} / \mathrm{t} / \mathrm{t} / \mathrm{and} / \mathrm{k} /$ if the sounds appear at the beginning of a word or syllable before stressed vowels as explained by Fromkin : "Aspirate voiceless stops at the beginning or a word or syllable before stressed vowels" (1978, p. 116). As a result, English learners whose Banjarese language background tend to not aspirate sounds $/ \mathrm{p} / \mathrm{/} / \mathrm{t} /$ and $/ \mathrm{k} /$ at the positions explained by Fromkin.

(7) Interference $\mathrm{j}$ is related to the absence of sounds /f/ and /v/ in Banjarese language. Thus, English learners whose Banjarese language background tend to replace sounds /f/ and /v/ with /p/ as sound /p/ is the closest sound to /f/ and /v/.

(8) Interference $\mathrm{k}$ is related to the system of English language which allows sounds $/ \mathrm{b} / \mathrm{.} / \mathrm{p} /, / \mathrm{d} /, / \mathrm{t} /, / \mathrm{g} /$ and $/ \mathrm{k} / \mathrm{to}$ appear at all positions (initial, middle, and final). In Banjarese language, sounds $/ \mathrm{b} /, / \mathrm{d} /$, and /g/ never appear at the final position and they are replaced with allophones $/ \mathrm{p} /, / \mathrm{t} /$, and $/ \mathrm{k} /$ respectively. This hinders English learners whose Banjarese language background to produce sounds $/ \mathrm{b} /, / \mathrm{d} /$, and $/ \mathrm{g} /$ at the final position in English and tend to replace them with sounds /p/, /t/, and /k/ respectively.

(9) Interference 1 is related to the absence of sounds $/ \theta /$ and $/ \delta /$ in Banjarese language. The closest sound to $/ \theta /$ is $/ \mathrm{t} /$, while the closest sound to $/ \delta /$ is $/ \mathrm{d} /$. English learners whose Banjarese language background tend to replace $/ \theta /$ with $/ \mathrm{t} /$ and $/ \delta /$ with $/ \mathrm{d} /$. 
(10) In interference $\underline{\mathrm{m}}$, sound /s/ and /z/ are pronounced as /s/ at the final position. Sounds /s/ and /z/ at the initial and middle position can be distinguished by learners. The replacement of sounds /s/ and /z/ is caused by the absence of sound /z/ in Banjarese language.

(11) Regarding interference $\underline{n}$, learners have difficulties in producing the sounds that do not exist in their language, namely $/ \mathrm{S} /$ and $/ 3 /$. This fact enforces them to replace these sounds with the closest sound, namely /s/.

\section{CONCLusions AND SugGestions}

\section{A. Conclusions}

Based on orientation results, field observation, data analysis and data interpretation as described in this report, several conclusions can be drawn as follows:

(a) Banjarese and English languages have major differences in terms of phonemes. Banjarese language only has 3 vowels (/a/, /i/ and /u/), while English has 12 vowels (/i:/, /ı/, /ع/, /æ/, /a/, /a:/, /っ/, /っ:/, /u/, /u:/, /ə/, and /ə:/. Moreover, Banjarese language has 18 consonants (/b/, /p/, /t/, /d/, /c/, /j/, /k/, /g/, /s/, /h/, /m/, /n/, /ny/, /y/, /1/, /r/, /w/, /y/). In

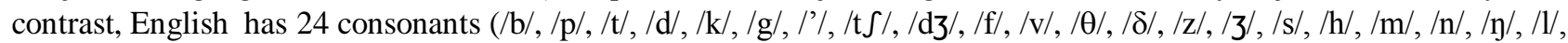
/r/, /w/, /y/).

Banjarese language has 3 diphthongs, namely /ai/, /au/, and /ui/, while English has 9 diphthongs, namely /eı/, /ou/, /aı/, /au/, /ol/, /ı/, /uə/, /عə/ and /oə/.

The major differences of phonemes and phonemic system between Banjarese language and English cause difficulties for students with Banjarese language background. As a result, linguistic phenomenon occurs, namely phonemic interference.

(b) The possibilities of interferences $\underline{b}$ and $\underline{\mathrm{d}}$ do not occur in students' utterances. In other words, interferences $\underline{b}$ and d were not found in this study although phonemes investigated using the instrument of this study do not exist in Banjarese language.

\section{B. Suggestions}

As the implications of the research results, the researcher suggests the followings:

(a) Lecturers, especially those who teach speaking course, are supposed to provide adequate pronunciation practice to their students and give accurate pronunciation model based on English phonemics.

(b) Students who still face many difficulties in the pronunciations English phonemes are suggested to do more practice individually and in groups.

(c) Future researchers are supposed to conduct similar research to obtain data of other two possibilities of interference which have not been found in this study.

\section{REFERENCES}

[1] Djinal, Aris et al. (1992). Interferensi Sintaksis Bahasa Indonesia pada Penggunaan Bahasa Inggris Tulis oleh Mahasiswa P.S. Pendidikan Bahasa Inggris FKIP Unlam Banjarmasin Angkatan Tahun 1989/1990. Laporan Penelitian. Banjarmasin: Puslit Unlam.

[2] Duradid, Durdje et al. (1978). Bahasa Banjar Hulu. Jakarta: Pusat Bahasa.

[3] Fishman (ed.). (1972). Reading in The Sociology of Language. The Haque-Paris: Mouton.

[4] Finocchiaro, Mary. (1975). English as a Second Language: From Theory to Practice. New York: Regent Publishing Company.

[5] Gleason, H.A. (1980). An Introduction to Descriptive Linguistics. Holt, Rinehart and Winston, Newyor K.

[6] Francis, Nelson. (1959). The Structure of American English. New York: The Ronald Press Company.

[7] Fromkin, Victoria and Robert Rodman. (1978). Introduction to Language. New York : Holt, Rinehart and Winston

[8] Koentjaraningrat. (1984). Metode-Metode Penelitian Masyarakat. Jakarta: Gramedia.

[9] Ramelan. (1977). English Phonetics: Part I. Semarang: IKIP.

[10] Ramelan. (1978). Introduction to Linguistic Analysis. Semarang: IKIP.

[11] Ramelan. (1984). Introduction to Linguistics for Students of English in Indonesia. Semarang: FPBS IKIP.

[12] Richards. (1985). Error Analysis: Perspective on Second Language Acquisition. Burnt Mill, Harlow, England: Longman Group Limited.

[13] Soetomo, Istiati. (1985). Telaah Sosial Budaya Terhadap Interferensi: Alih-Kode dan Tunggal Bahasa pada Masyarakat Gandabahasa. Disertasi. Jakarta: UI.

[14] Weinrich, Urial. (1968). Languages in Contact: Findings and Problems. The Haque-Paris: Mouton.

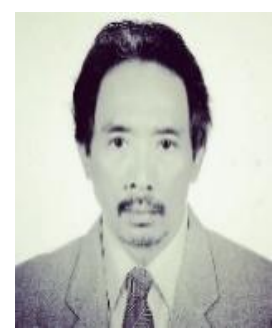

Fatchul Mu'in is a Lecturer in Linguistics at Universitas Lambung Mangkurat, Banjarmasin, South Kalimantan, Indonesia. He earned his Master of Humanities from Universitas Gadjah Mada, Yogyakarta, Indonesia and Doctor degree from Universitas Negeri Malang, East Java, Indonesia. 